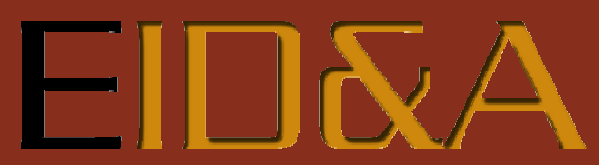

Revista Eletrônica de Estudos Integrados em Discurso e Argumentação

http://dx.doi.org/10.17648/eidea-15-1909

\title{
ERRO DE PROIBIÇÃO E ESTUPRO DE VULNERÁVEL: ANÁLISE ARGUMENTATIVA DE ACÓRDÃO JUDICIAL
}

\author{
Marcelo Pereira Neves ${ }^{\mathrm{i}}$ \\ Gilberto Nazareno Telles Sobral ${ }^{\mathrm{ii}}$
}

\begin{abstract}
Resumo: Este trabalho analisa a fundamentação do Acórdão $\mathrm{n}^{\circ}$ 000049927.2011.8.05.0246 por meio das categorias argumentativas propostas por Perelman e Olbrechts-Tyteca (2005), identificando os elementos da tríade retórica observados no corpus. A partir desse foco de análise, o trabalho se debruça inicialmente sobre o ethos construído na decisão, valendo-se dos esquemas traçados por Maingueneau (2008). Em seguida, apoia-se em Santana Neto para analisar os elementos componentes do pathos. Observando o logos decisório, a análise indica que os magistrados empregam técnicas argumentativas de diversas espécies para relativizar determinados critérios legais objetivos e absolver os réus. Na conclusão, destaca-se a importância da dimensão argumentativa para a fundamentação de decisões judiciais.
\end{abstract}

Palavras-Chave: Argumentação. Tríade Retórica. Decisão Judicial. Estupro de Vulnerável.

Abstract: This work analyzes the reasoning of Judgment $n^{\circ}$ 000049927.2011.8.05.0246 through argumentative categories proposed by Perelman and Olbrechts-Tyteca (2005), identifying the elements of the rhetorical triad that make up the corpus. The work initially focuses on the ethos constructed in the decision, using the schema outlined by Maingueneau (2008). It relies on Santana Neto to analyze the component elements of pathos. Looking at the decision's logos, it shows how magistrates use various argumentative techniques to relativize certain objective legal criteria and absolve the defendants. It concludes by determining the importance of the argumentative dimension for the reasoning of judicial decisions.

Keywords: Argumentation. Rethorical Triad. Judicial Decision. Statutory Rape.

\footnotetext{
' Mestrando pelo Programa de Pós-Graduação em Estudos de Linguagens da Universidade do Estado da Bahia (UNEB), Brasil. E-mail: mneves83@yahoo.com.br.

ii Professor Doutor do Programa de Pós-Graduação em Estudo de Linguagens da Universidade do Estado da Bahia (UNEB), Brasil. E-mail: gsobral@uneb.br.
} 
EID\&A - Revista Eletrônica de Estudos Integrados em Discurso e Argumentação, llhéus, n. 15, jan./jun.2018.

\section{Introdução}

O estudo das técnicas argumentativas empregadas com o objetivo de convencer determinada audiência, denominado Retórica, tem sua origem em um contexto de prática da atividade judiciária. Fiorin (2016, p. 22), recorrendo a Barthes, aponta os conflitos pela posse de terras na Sicília do século IV a. C. como o marco inicial do estudo e ensino da arte da argumentação pelos sofistas. Desde então, a ciência do Direito tornou-se mais rebuscada para acomodar as transformações socioeconômicas inerentes ao percurso histórico humano, porém jamais se despiu da necessidade da argumentação. A prática jurídica orienta-se principalmente por meio dos Princípios de Direito e da técnica processual legal, mas a necessidade do convencimento permanece, e a argumentação ainda figura como instrumento principal para sua obtenção.

Embora a observação mais óbvia do caráter argumentativo do campo jurídico repouse na figura do advogado que busca o convencimento do juiz e do júri, não é essa a cena que interessa à lente do presente artigo. Desejamos analisar o componente retórico presente na decisão proferida pela magistratura, que, embora investida de toda a autoridade do Estado, não se encontra dissociada do elemento retórico. Particular interesse de análise despertam as decisões relativas às circunstâncias sobre as quais a norma pura - argumento máximo de autoridade - não é capaz de subsumir com perfeição o caso concreto. Sob esses contornos, uma decisão judicial expressaria um juízo de valor. Reboul (2004, p. 88-89) sintetiza o pensamento de Perelman e Olbrechts-Tyteca sobre a questão: “[...] [os] autores partiram de um problema, não linguístico nem literário, mas filosófico: como fundamentar os juízos de valor? [...]" Aponta, em seguida, a solução proposta pelos autores: "Buscaram pois, a lógica do valor, paralela à da ciência, e acabaram por encontrá-la na antiga retórica, completada, como convém, pela dialética" (REBOUL, 2004, p. 89).

Perelman se debruça sobre a atividade jurisdicional e relaciona a prolação de decisões às técnicas argumentativas descritas em sua Teoria da Argumentação. Opera uma aproximação entre as lógicas argumentativa e judiciária, de forma a propiciar a análise do raciocínio dos juristas - e juízes como uma argumentação organizada de acordo com as concepções do Direito e sua função social, sustentadas pela magistratura.

O fato de o juiz submeter-se à lei ressalta a primazia concedida ao poder legislativo na elaboração das regras de direito. Mas disso não resulta, de modo 
EID\&A - Revista Eletrônica de Estudos Integrados em Discurso e Argumentação, Ilhéus, n. 15, jan./jun.2018.

algum, um monopólio do legislativo na formação do direito. 0 juiz possui, a este respeito, um poder complementar indispensável que lhe permitirá adaptar a lei a casos específicos. Se não lhe reconhecessem tal poder, ele não poderia, sem recorrer a ficções, desempenhar sua missão, que consiste no solucionamento dos conflitos: a natureza das coisas obriga a conceder-lhe um poder criativo e normativo no domínio do direito (PERELMAN, 1998, p. 203).

É por meio da retórica que uma decisão judicial deve ser fundamentada. O próprio código de processo civil, em seu artigo 489, II, nomeia os "fundamentos" como elemento essencial de uma sentença. A ausência de fundamento, ou sua deficiência, enseja recurso, que pode acarretar a anulação ou reforma da decisão em questão. Pode-se dizer, portanto, que uma decisão judicial necessita convencer seu auditório de que está bem fundamentada, tanto por elementos estritamente legais quanto axiológicos, ligados a princípios e parâmetros de constitucionalidade.

Quanto ao corpus analisado, trata-se do Acórdão $\mathrm{n}^{\circ}$ 000049927.2011.8.05.0246, absolutório, proferido em sede de recursos de apelação interpostos diante de sentença penal condenatória. Teriam os réus sido condenados em primeira instância pelos crimes de estupro de vulnerável (Art. 217-A c/c Art. 71 do Código Penal Brasileiro, doravante CPB) e omissão penalmente relevante (Art. 13, $\S 2^{\circ}, \mathrm{CPB}$ ). O referido acórdão reformou a decisão para determinar a absolvição de ambos os réus com base no Art. 386, $\mathrm{VI}$, do Código de Processo Penal, correspondente ao reconhecimento da existência de circunstâncias que excluam o crime ou isentem o réu de pena.

O processo abordou o envolvimento sexual entre o réu H. J. A. e E. S. S., que à época era menor de 14 anos de idade, configurando para todos os efeitos o crime descrito pelo Art. 217-A do CPB. A genitora da vítima, C. S. R. A., por ter permitido o referido envolvimento, tendo determinado que a filha passaria a morar com o réu em vista seu relacionamento, figurou também como ré.

O crime de estupro de vulnerável, tipificado no CPB, não considera que a existência do consentimento da vítima seja capaz de afastar, por si só, a ilegalidade da conduta, sob o pressuposto de proteger a sua vulnerabilidade. Por envolver direitos especialmente protegidos pela Constituição, coube ao Ministério Público oferecer denúncia, independente da vontade da própria vítima.

Após a condenação, o réu interpôs recurso, resultando no referido acórdão. As circunstâncias capazes de isentar os réus de pena foram diversas 
EID\&A - Revista Eletrônica de Estudos Integrados em Discurso e Argumentação, llhéus, n. 15, jan./jun.2018.

e apresentadas na fundamentação decisória. Identificou-se o consentimento da ofendida em manter um relacionamento com o réu, que construiria uma casa para que ambos pudessem conviver maritalmente. Foi também apontado o contexto social da comunidade em que viviam os envolvidos - o povoado de Teles, na Bahia - onde o relacionamento entre ambos era conhecido e aceito como algo costumeiro no povoado. Ademais, a própria mãe da vítima teria iniciado sua vida sexual em idade semelhante e engravidado precocemente. Todos esses fatos indicavam um desconhecimento - baseado em circunstâncias juridicamente relevantes - do caráter criminoso da conduta pelas partes envolvidas.

O presente corpus apresenta um campo fértil para a análise da configuração da tríade retórica no âmbito das decisões judiciais e sua fundamentação. Por não se tratar de um caso concreto no qual a mera aplicação literal da lei é solução suficiente, tais elementos retóricos emergem mais facilmente do estudo do texto. O crime de estupro de vulnerável é rigidamente definido pela lei, que não admite existência de consentimento por parte da vítima quando for menor de 14 anos. O tema é objeto de discussão ainda não pacificada entre juristas, sendo a opinião majoritária da doutrina atual bem representada na lição de Nucci:

\footnotetext{
Verifica-se, pois, que a definição de patamar etário para a caracterização da vulnerabilidade é baseada numa ficção jurídica, que nem sempre encontrará respaldo na realidade do caso concreto, notadamente quando se leva em consideração o acentuado desenvolvimento dos meios de comunicação e a propagação de informaç̃os, que acelera o desenvolvimento intelectual e capacidade cognitiva das crianças e adolescentes.
}

Cremos que o legislador, ao editar o dispositivo em análise, afastou-se novamente da realidade social, vez que ignorou não só a precocidade das crianças e adolescentes, como persistiu em utilizar um critério etário para definir aqueles que em hipótese alguma podem manter relações sexuais. Por tais razões é que defendemos a relativização de sua vulnerabilidade (GUILHERME..., 2010, grifos nossos).

Se a Turma Recursal pretender considerar a presença do consentimento do ofendido no caso concreto, deverá empregar estratégia retórica tal que justifique a decisão, amparando-se em posicionamentos doutrinários, princípios de direito, entre outros elementos, haja vista a exigência legal de ignorar a possibilidade de consentimento do menor de 14 anos.

A tríade retórica perpassa toda a materialidade argumentativa, com seus elementos entremeando-se ao discurso, e se manifesta com diferente 
EID\&A - Revista Eletrônica de Estudos Integrados em Discurso e Argumentação, llhéus, n. 15, jan./jun.2018.

intensidade a cada momento. Porém, para tornar mais didática a presente análise, partiremos da caracterização do ethos, seguida do pathos e finalmente do logos que se depreendem do corpus delimitado, evidenciando, porém, o modo como se relacionam ao longo texto, posto que são componentes indissociáveis da argumentação.

\section{Identificando marcas de ethos}

O ethos refere-se à identidade do orador, como é projetada por meio de sua fala e como é percebida pelo auditório a quem se dirige. Fiorin (2016) o decompõe em três elementos básicos: o caráter, evidenciado pelas características psíquicas que o enunciador demonstra; o corpo, representado pelas características físicas - que podem ser projetadas, inclusive, a partir do texto - e o tom, dimensão vocal encontrada no discurso. As marcas do ethos podem ser depreendidas de elementos recorrentes em uma materialidade discursiva, como a escolha do tema, o nível de linguagem empregado, o ritmo do texto etc.

No caso observado, o papel de orador recai sobre a Primeira Turma Recursal da Primeira Câmara Criminal do Tribunal de Justiça do Estado da Bahia, órgão colegiado composto por no mínimo três desembargadores. Deve-se tomar o voto como discurso proferido pela turma em sua coletividade, enquanto órgão jurisdicional.

Denota-se da condição de decisão judicial do texto a presença de um ethos fixado e implícito de autoridade jurisdicional. A observação do corpo textual revela uma escassez de marcas de subjetividade. A Turma Recursal refere-se a si própria apenas no segundo parágrafo após a ementa processual da página quatro do acórdão, somente na terceira pessoa, designando-os somente pela função ocupada em relação ao presente julgado: "É, em síntese, o relatório, que submeto à apreciação do Eminente Desembargador Revisor" (TJ-BA, 2015, p. 2).

Recorrendo a Maingueneau (2008), é possível identificar que o campo jurídico produz textos - incluso aqui o gênero acórdão judicial, ao qual pertence o corpus - nos quais há o apagamento do enunciador. Não obstante, é possível caracterizar a presença de um ethos, pois, assim como no gênero científico, a imagem do orador é além do indivíduo, uma entidade coletiva no presente caso, os "homens e mulheres do Direito" - representante de uma 
EID\&A - Revista Eletrônica de Estudos Integrados em Discurso e Argumentação, llhéus, n. 15, jan./jun.2018.

entidade abstrata - "o Direito". A fala jurídica está intimamente associada a um mundo ético bem caracterizado, que alude a noções do devido processo legal e de um proceder baseado na fidelidade aos princípios de direito. Essa caracterização certamente não é unívoca no tocante à visão de determinados auditórios. Porém, considerando o auditório como as partes do processo, satisfeitas com a decisão que as absolve, unido à própria comunidade jurídica, não se observa rejeição à caracterização do ethos da Primeira Turma Recursal do Estado da Bahia como representantes de uma entidade abstrata que corporifica o próprio Direito.

Maingueneau (2008) esquematiza a formação do ethos efetivo do orador, manifesto em um discurso, a partir da confluência de múltiplos ethé:

O ethos de um discurso resulta de uma interação de diversos fatores: ethos prédiscursivo, ethos discursivo (ethos mostrado), mas também de fragmentos do texto em que o enunciador evoca sua própria enunciação (ethos dito): diretamente ('é um amigo que Ihes fala'), ou indiretamente, por exemplo, por meio de alusões a outras cenas de fala [...] A distinção entre ethos dito e ethos mostrado inscreve-se nos extremos de uma linha contínua, já que é impossível definir uma fronteira nítida entre o "dito" sugerido e "mostrado". O ethos efetivo, o que tal ou qual destinatário constrói, resulta na interação dessas diversas instâncias, cujo peso respectivo varia segundo os gêneros do discurso (MAINGUENEAU, 2008, p. 71).

Quanto ao ethos pré-discursivo, destaca-se a supramencionada imagem de ente coletivo, representante da autoridade do Direito. Trata-se de uma noção previamente estabelecida a partir dos estereótipos atribuídos à magistratura enquanto figuras de autoridade, dotadas de grande saber jurídico e tendentes ao proceder, se não completamente imparcial, ao menos amparado na legalidade. São elementos atribuídos ao ethos antes mesmo que o discurso seja efetivamente produzido, adstritos ao título de Desembargador.

O ethos discursivo da decisão sob análise é caracterizado pela ausência de marcas de pessoalidade. Conforme os trechos previamente extraídos do acórdão, percebe-se que há pouca referência à figura da Turma Recursal e seus membros, que são referidos por suas funções, de forma impessoal. Essa impessoalidade funciona para amplificar a relevância da dimensão prédiscursiva do ethos, os estereótipos de autoridade e imparcialidade atribuídas aos membros da magistratura.

Por evitar marcas de subjetividade, minimizando o ethos discursivo no texto que produz, a Turma Recursal permite que esse ethos pré-discursivo formado pelo sólido estereótipo ético do Juiz Natural preencha o ethos 
EID\&A - Revista Eletrônica de Estudos Integrados em Discurso e Argumentação, Ilhéus, n. 15, jan./jun.2018.

efetivo. Esse ethos discursivo mínimo é sempre mostrado e nunca dito, indicado, dentre outros fatores, pela predileção da Turma por expressar-se por meio de citações, principalmente das partes e dos elementos do conjunto probatório para narrar os fatos, conforme se extrai da leitura do corpus: "Além disso, a Apelante confirmou os relatos judiciais da vítima, e, malgrado figurar como Ré na respectiva Ação Penal, ainda assim disse querer 'que Hilton vá morar com Eduarda e se casem direitinho na igreja'(sic)” (TJ-BA, 2015, p. 6).

O Acórdão recorre também à autoridade da lei para evidenciar situações juridicamente relevantes:

Sob essa ótica, constata-se que o caso vertente enquadra-se no quanto disposto na primeira parte do art. 21 da Lei Adjetiva Penal, in litteris: o desconhecimento da lei é inescusável. O erro sobre a ilicitude do fato, se inevitável, isenta de pena (TJ-BA, 2015, p. 8).

A Turma Recursal, na decisão analisada, cita até mesmo a manifestação da Procuradora de Justiça para corroborar a sua posição quanto ao caso em julgamento, outra forma de suscitar o argumento de autoridade:

Mister ressalvar excertos do Parecer da Douta Procuradora de Justiça Luiza Pamponet Sampaio Ramos, os quais dilucidam em idêntica linha intelectiva (fls.399/400): [...] chega-se à conclusão de que os agentes efetivamente acreditavam que estavam agindo acobertados por uma excludente de ilicitude, em razão da convivência marital entre o acusado e Eduarda. Trata-se de hipótese de erro de proibição indireto, portanto, pois os réus entendiam que, assumido o relacionamento por Hilton José, não haveria qualquer ilicitude em sua conduta. [...] vale dizer que, no caos em questão, os réus agiram acobertados por erro de proibição escusável ou invencível, o que exclui a própria culpabilidade. Não se pode dizer que o erro era vencível ou inescusável, uma vez que, conforme restou exaustivamente comprovado, toda a comunidade de Teles considerava o relacionamento entre o acusado e a adolescente como algo natural. Por mais abjeto que isso possa parecer é a triste realidade de muitas comunidades rurais brasileiras, distantes de centros urbanos (TJ-BA, 2015, p. 8).

\section{Os elementos do pathos}

O pathos diz respeito às emoções do auditório e sua comoção em relação ao discurso do orador. Perelman e Olbrechts-Tyteca (2005) reconhecem a extrema importância de se considerar as características do auditório na elaboração de um argumento capaz de persuadir ou convencer:

Esse contato entre o orador e seu auditório não concerne unicamente às condições prévias da argumentação: é essencial também para todo o desenvolvimento dela. Com efeito, como a argumentação visa obter a adesão 
EID\&A - Revista Eletrônica de Estudos Integrados em Discurso e Argumentação, Ilhéus, n. 15, jan./jun.2018.

daqueles a quem se dirige, ela é por inteiro, relativa ao auditório que procura influenciar (PERELMAN; OLBRECHTS-TYTECA, 2005, p. 21).

Uma decisão judicial dirige-se simultaneamente às partes do processo, à comunidade jurídica - os atores e estudiosos do campo do direito - e à sociedade a qual serve o Poder Judiciário. Deve-se, sob as circunstâncias do corpus analisado, considerar como o efetivo auditório: os indivíduos aos quais se pretende persuadir pelo discurso. No caso abordado, são primeiramente as partes do processo, que estarão legitimadas a manejar um recurso judicial apropriado; em segundo lugar, estão inclusos no auditório os membros da comunidade jurídica em geral, posto que a produção de uma decisão de segundo grau contribui para a formação de jurisprudência, isto é, trata-se de uma tendência a julgar casos semelhantes de acordo com decisões pregressas.

Uma decisão que não apresente fundamentação satisfatória certamente atrairá críticas por parte de acadêmicos e doutrinadores do Direito, de outros membros da magistratura e de Tribunais Superiores. Dessa forma, deve-se tomar como argumento bem-sucedido aquele capaz de persuadir a comunidade jurídica, aqui compreendida como os juízes e tribunais superiores, bem como o Ministério Público e a advocacia, que são os membros do auditório efetivamente capazes de influenciar no resultado final de um processo, acatando ou repudiando uma decisão com base nos argumentos que a sustentam.

Por absolvê-los, o acórdão sob análise tenta garantir a adesão dos acusados, buscando alcançar o pathos dos demais membros do auditório. Falar em comoção quando o texto é dirigido à comunidade jurídica parece contraditório, mas existe um pathos a ser identificado nessa parcela do auditório, correspondente ao formalismo e ao devido processo legal. Perelman e Olbrechts-Tyteca (2005) asseveram que os ouvintes costumam adotar posturas ligadas às funções sociais que lhes são atribuídas. Desse modo, os representantes das partes envolvidas, bem como o Ministério Público, enquanto fiscal da Lei e representante da sociedade no processo penal, apresentam-se na forma de um auditório movido pela correição jurídico-normativa, apresentando uma disposição favorável a argumentos embasados na legalidade e constitucionalidade, uma vez que é sua função social zelar pelo devido cumprimento das normas materiais e processuais envolvidas na produção de decisão que possa ser considerada como “justa”. 
EID\&A - Revista Eletrônica de Estudos Integrados em Discurso e Argumentação, Ilhéus, n. 15, jan./jun.2018.

Os argumentos envolvidos na fundamentação do acórdão estudado consistem na tese de que as partes envolvidas no processo foram incapazes de compreender a ilegalidade da conduta praticada. Essa incompreensão não teria ocorrido por mero desconhecimento da lei, mas por força da realidade social da qual fazem parte. Desse modo, o desconhecimento da ilegalidade torna-se um argumento juridicamente válido.

Esses argumentos se manifestam por meio de referências a laudos periciais e ao Código de Processo Penal, conforme os seguintes trechos extraídos do corpus:

A materialidade delitiva está demonstrada nos autos de forma irrefragável: a cópia da Certidão de Nascimento de fl. 84 atesta que Eduarda dos S. S. nasceu no dia 06.04.1999; o Laudo de Constatação Carnal de fls. 76/77 atestou ser a menor desvirginada, estando, ainda, em estado gravídico; o Laudo de Ultrassonografia Obstétrica de fl. 18 confirmou a gravidez da menina, bem como a Certidão de Nascimento de fl. 161 registrou o nascimento da criança em 25.01.2012; além da prova testemunhal (TJ-BA, 2015, p. 05).

Ora, consoante demonstrado de maneira satisfatória alhures, fatores consuetudinários verdadeiramente obstaram que HILTON JOSÉ DE ANDRADE e CLEIDE DOS SANTOS RODRIGUES ANDRADE possuíssem, por completo, a condição de alcançar à consciência da ilicitude dos fatos, revelando-se, in casu, a manifesta ocorrência de erro de proibição invencível, ao que devem os Apelantes serem absolvidos com fulcro no art. 386, inciso VI, do Código de Processo Penal (TJ-BA, 2015, p. 08).

Santana Neto (2008), para analisar as emoções do auditório no contexto argumentativo, propõe partir de pressupostos da teoria clássica aristotélica, da nova retórica e da pragmática e a divisão do pathos em pathos prédiscursivo e pathos discursivo. O primeiro ligado às emoções do auditório previstas pelo orador, o segundo atrelado às emoções reveladas pelo auditório na produção do discurso. Quanto ao pathos discursivo, apresenta a seguinte distinção:

O páthos discursivo ainda pode ser dividido em páthos encenado e páthos do auditório. Quando o orador utiliza-se da cenografia a fim de criar uma realidade verossímil na qual as personagens revelam as suas paixões, tem-se o páthos encenado, que influencia o páthos (comoção) do auditório, o qual, por sua vez, apresentam as paixões do auditório propriamente ditas, isto é, na influência afetiva obtida pelo discurso do orador (SANTANA NETO, 2008).

Aplicando-se tal modelo ao corpus em tela, percebe-se no acórdão a tentativa de dar conta de um pathos pré-discursivo de ojeriza ao crime de estupro de vulnerável, nominalmente no primeiro parágrafo da página oito, ao 
EID\&A - Revista Eletrônica de Estudos Integrados em Discurso e Argumentação, Ilhéus, n. 15, jan./jun.2018.

evidenciar o erro de proibição como juízo contrário aos parâmetros sociais, bem como na fala recortada da Procuradora de Justiça:

\begin{abstract}
Por mais abjeto que isso possa parecer é a triste realidade de muitas comunidades [...] Sobre a figura jurídica do erro de proibição, caracteriza-se a partir do artigo 21 do Código Penal Brasileiro como o erro sobre a ilicitude de um fato, ou seja, o desconhecimento de que determinada conduta constitui crime. Tal desconhecimento, quando inevitável, assevera o CPB, isenta de pena. A evitabilidade ou inevitabilidade do erro deve ser definida a partir do estudo do caso concreto, cabendo portanto à Turma Recursal fundamentar argumentativamente a aplicação do supracitado instituto (TJ-BA, 2015, p. 8).
\end{abstract}

A Turma Recursal aponta compreender e partilhar os valores da sociedade, admitindo o elevado grau de reprovabilidade da conduta praticada, mas deslocando o foco do argumento para o contexto social em que o suposto crime teria ocorrido. Extraímos dos depoimentos citados a situação de precariedade de infraestrutura do povoado de Teles, correlacionando-a à falta de instrução que levou ao desconhecimento da ilegalidade da conduta praticada:

Das testemunhas ouvidos em juízo, todas moradores do povoado e que conheciam os envolvidos mostraram, dessume-se que eles não sabiam que tratava-se de crime um rapaz relacionar-se com uma pessoa menor, sendo tal situação comum naquela localidade - a qual, frise-se, não possui energia elétrica nem água encanada, consoante relatou a vítima-, principalmente quando, no caso de gravidez, eles se casavam (fls. 152/158) (TJ-BA, 2015, p. 7).

Essa informação de que os supostos ofensores e a vítima viviam em situação marital é associada ao planejamento de construir a própria casa e constituir família:

E mais, a realidade trazida ao acertamento jurisdicional pelos referidos testemunhos assinala que a comunidade em que estavam inseridos sabia e concordava com o relacionamento, até mesmo que o Réu estava construindo uma casa para viverem juntos e constituírem família, sendo este tipo de situação considerada costumeira no Povoado de Teles (TJ-BA, 2015, p. 7).

O acórdão cria uma cenografia a partir da realidade desses indivíduos um pathos encenado - tendente a alcançar o pathos do auditório por meio de estereótipos da comunidade carente, sem instrução e desprovida de conhecimento jurídico, bem como de uma ideia de núcleo familiar em formação. 
EID\&A - Revista Eletrônica de Estudos Integrados em Discurso e Argumentação, Ilhéus, n. 15, jan./jun.2018.

\title{
3. Principais argumentos do logos
}

O logos se refere ao componente racional da argumentação, as estratégias e técnicas argumentativas selecionadas pelo orador para promover a adesão de espíritos com seu auditório. O logos de um discurso argumentativo pode se configurar de múltiplas formas, imbricando diversas técnicas argumentativas, distintas na construção de uma estratégia argumentativa, tornando patente a necessidade de se empregar múltiplas técnicas em um mesmo argumento:

\begin{abstract}
É levando em conta essa sobreposição de argumentos que se conseguirá explicar melhor o efeito prático, efetivo, da argumentação. Toda análise que a preterisse estaria, pensamos, condenada ao fracasso. Contrariamente ao que se passa numa demonstração da qual os procedimentos demonstrativos ocorrem no interior de um sistema isolado, a argumentação caracteriza-se por uma interação constante entre todos os seus elementos. Sem dúvida, mesmo a demonstração lógica pode ser objeto de atenção da parte do ouvinte, que lhe admitirá a elegância, lhe deplorará o desprimor, constatará sua adequação à meta perseguida. Mas essa argumentação que toma a demonstração por objeto não será ela própria demonstração. Não se sobreporá à demonstração para modificar-lhe a validade. Desenvolver-se-á num plano argumentativo em que encontraremos precisamente os argumentos retóricos que estamos analisando (PERELMAN; OLBRECHTS-TYTECA, 2005, p. 214-215).
\end{abstract}

Partindo das categorias estabelecidas por Perelman e Olbrechts-Tyteca na análise das técnicas argumentativas utilizadas, é possível identificar um conjunto principal de argumentos interrelacionados no corpus sob análise. Trata-se principalmente de argumentos baseados na estrutura do real, apoiados em uma determinada interpretação da realidade para alcançar a adesão dos espíritos. Tais argumentos, asseveram de Perelman e OlbrechtsTyteca (2005), buscam promover relações de solidariedade entre valores previamente aceitos e aqueles que a argumentação pretende corroborar, estabelecendo ligações hierárquicas, de causa-efeito, de coexistência, entre outras. Tais ligações argumentativas são variadas e complexas, uma vez que derivam da concepção particular de realidade apresentada pelo orador, que pode inclusive divergir da realidade concebida pelo auditório.

Em se tratando de uma decisão judicial, não é surpreendente que o argumento de autoridade figure como técnica argumentativa prevalente ao longo de todo o acórdão. Os autores (2005) classificam o argumento de autoridade como aquele que se vale do juízo ou atos de uma terceira pessoa ou grupo e pessoas para validar determinada tese com base no prestígio ostentado por tal pessoa ou grupo. Embora consista em uma forma 
EID\&A - Revista Eletrônica de Estudos Integrados em Discurso e Argumentação, Ilhéus, n. 15, jan./jun.2018.

argumentativa bastante criticada pelo viés aparentemente coercitivo e por não se preocupar com o que é verdadeiro ou falso, sua importância prática é especialmente reconhecida no tocante ao Direito:

Mas não é uma ilusão deplorável crer que os juristas se ocupam unicamente com a verdade, e não com justiça nem com paz social? Ora, a busca da justiça, a manutenção de uma ordem equitativa, a confiança social, não podem deixar de lado as considerações fundamentadas na existência de uma tradição jurídica, a qual se manifesta tanto na doutrina quanto na jurisprudência. Para atestar a existência de semelhante tradição, o recurso ao argumento de autoridade é inevitável (PERELMAN; OLBRECHTS-TYTECA, 2005, p. 349).

O argumento de autoridade, constituído pelas palavras dos juristas, tende a ser específico, invocando o prestígio de indivíduos cuja competência é reconhecida pelo auditório, de modo que o apelo à doutrina e à jurisprudência, em conjunto com a norma pura, complementa muito bem qualquer argumentação no campo jurídico, que de comum acordo já aceita ou mesmo exige o recurso à autoridade como forma de corroborar uma tese.

A análise do ethos e do pathos discursivos já demonstra os estereótipos de rigidez, impessoalidade e justiça associados ao discurso jurídico. É razoável antever que qualquer argumento destinado a persuadir um auditório composto pela comunidade jurídica ou parte dela deva revestir-se de autoridade, ainda que apenas para suprir as expectativas de um pathos prédiscursivo e inscrever um ethos filiado à tradição jurídica. No presente corpus, pode-se identificar a todo momento o recurso à autoridade do legislador ao fazer constante remissão aos institutos da legislação penal, a exemplo do art. 21, relativo à figura do erro de proibição:

Oportunizada sua manifestação, a Douta Procuradora de Justiça Luiza Pamponet Sampaio Ramos opinou pelo conhecimento e provimento do Recursos, sendo os Acusados absolvidos da imputação de Estupro de Vulnerável, com fulcro no art. 21 do CPB c/c o art. 386, inciso VI do CPP, em razão da ausência sequer da potencial consciência da ilicitude [...] (TJ-BA, 2015, p. 02).

Ou o art. 386, IV do Código de Processo Penal:

ACORDAM os Desembargadores integrantes da $1^{\mathrm{a}}$ Turma Julgadora da $1^{\mathrm{a}}$ Câmara Criminal do Tribunal de Justiça do Estado da Bahia em CONHECER dos Recursos de Apelação interpostos e DAR-LHES PROVIMENTO para absolver HILTON JOSÉ DE ANDRADE e CLEIDE DOS SANTOS RODRIGUES ANDRADE da imputação do crime de Estupro de Vulnerável (art. 217-Ac/coart.71 ambos do CPB), com supedâneo no art. 386, inciso VI, do Código de Processo Penal, tudo nos termos do voto da Relatora (TJ-BA, 2015, p. 04). 
EID\&A - Revista Eletrônica de Estudos Integrados em Discurso e Argumentação, llhéus, n. 15, jan./jun.2018.

É essa autoridade legal, junto ao ethos pré-discursivo da magistratura investida de poder decisório, que vai sustentar os demais argumentos presentes no acórdão, provendo uma estrutura sobre a qual a fundamentação pode ser construída.

Observa-se também o recurso à autoridade técnica por meio da remissão a diversos laudos periciais para determinar a existência da conduta sexual praticada entre o Réu e a suposta vítima:

A materialidade delitiva está demonstrada nos autos de forma irrefragável: a cópia da Certidão de Nascimento de fl. 84 atesta que Eduarda dos S. S. nasceu no dia 06.04.1999; o Laudo de Constatação Carnal de fls. 76/77atestou ser a menor desvirginada, estando, ainda, em estado gravídico; o Laudo de Ultrassonografia Obstétrica de fl. 18 confirmou a gravidez da menina, bem como a Certidão de Nascimento de fl. 161 registrou o nascimento da criança em 25.01.2012; além da prova testemunhal (TJ-BA, 2015, p. 05).

Não se trata do recurso à doutrina ou jurisprudência, mas se apoia na competência dos peritos para atestar que a vítima teria efetivamente se relacionado sexualmente com o réu e confirmar sua gravidez. A remissão ao testemunho da ofendida também configura o emprego do argumento de autoridade, baseado na sua inocência, por ser ainda menor de idade, e na pressuposição de que não possuiria qualquer interesse em falsear seu testemunho para absolver os acusados

Eduarda dos S. S., ouvida em juízo às fls. 106/107, afirmou que iniciou seu relacionamento com o Réu quando ainda era virgem, ocorrendo a conjunção carnal em janeiro de 2011. Os encontros aconteciam, de forma escondida, na casa dele e sua mãe e seu padrasto não tinham conhecimento disso, pois sua genitora a proibia de namorar. Tanto que, escondeu sua gravidez do Réu até o primeiro mês de gestação, vindo a revelar o seu estado para CLEIDE DOS SANTOS RODRIGUES apenas no terceiro mês. Disse a vítima que depois que revelou sua gestação para HILTON JOSÉ DE ANDRADE ele quis ir falar com sua mãe para assumir o filho, porém a ofendida só contou para sua genitora em maio de 2011 (TJ-BA, 2015, p. 6).

Uma última ocorrência do argumento de autoridade é a citação do parecer da procuradora de justiça em relação à ocorrência do erro de proibição, na página oito. O acórdão apropria-se do argumento da procuradora, cuja opinião demonstra valorizar ao tratá-la por "douta", corroborando a incidência do art. 21 do CPB no caso concreto. Mais uma vez cumpre ressaltar que essa preponderância do apelo à autoridade reforça $O$ apagamento de marcas de um ethos corpóreo individual, ao mesmo tempo em que tenciona alcançar o pathos de uma comunidade jurídica que valoriza a 
EID\&A - Revista Eletrônica de Estudos Integrados em Discurso e Argumentação, Ilhéus, n. 15, jan./jun.2018.

precisão técnica da decisão, que deve se adequar ao rigor formal imposto pela Lei. Cria-se portanto a sensação de que o acórdão existe por si próprio, como manifestação da própria Justiça, e não como discurso produzido e fundamentado por magistrados desembargadores que foram instados a fazêlo em resposta a um recurso judicial.

Talvez mais interessante para a análise argumentativa seja a aplicação da figura jurídica do erro de proibição, constante no Art. 21 do Código Penal como forma de justificar a absolvição. O referido artigo diz o seguinte:

Art. 21 - O desconhecimento da lei é inescusável. O erro sobre a ilicitude do fato, se inevitável, isenta de pena; se evitável, poderá diminuíla de um sexto a um terço (Redação dada pela Lei $n^{\circ}$ 7.209, de 11.7.1984).

Parágrafo único - Considera-se evitável o erro se o agente atua ou se omite sem a consciência da ilicitude do fato, quando lhe era possível, nas circunstâncias, ter ou atingir essa consciência (Redação dada pela Lei nº 7.209, de 11.7.1984).

Não basta simplesmente evocar o Art. 21 para isentar o réu de pena. É necessário demonstrar que houve um erro inevitável quanto à ilegalidade do ato, ou seja, que não era possível para o indivíduo, dadas as circunstâncias, compreender que sua conduta era ilícita. Para tal efeito, o acórdão se utiliza das ligações de coexistência a partir da interação entre ato e pessoa especificamente a interpretação pela intenção - paralelamente às técnicas de refreamento dessa interação ato-pessoa, bem como à de aproximação do indivíduo ao grupo, buscando criar uma unidade de sentido capaz de fundamentar a tese da ocorrência do erro de proibição inevitável ou escusável, conforme exemplifica o seguinte trecho do acórdão:

Diante de toda a conjuntura delineada no caso em testilha e de tudo mais que abrange os fatos, mostra-se, perfunctoriamente, crível que as condições pessoais dos Apelantes somadas às circunstâncias de entorno impediram a compreensão deles acerca da proibição da conduta de ter conjunção carnal com menor de 14 anos; na pior das hipóteses, acreditavam que somente se o Réu não assumisse a gravidez proveniente das relações que teve com Eduarda - sendo irrelevante o fato dela ser ou não menor-ocasionaria alguma tipo de "problema", sem saberem que este revés configuraria uma ilícito penal (TJBA, 2015, p. 7-8).

As ligações de coexistência indicadas acima, segundo Fiorin (2016, p. 170), relacionam determinado atributo a um ato ou pessoa. Para elucidar o modo como o acórdão entrecruza essas técnicas, recorremos a Perelman e Olbrechts-Tyteca (2005) que, ao tratar da interação entre ato e pessoa nessas ligações, afirmam que o valor atribuído a um ato tende a ser transferido ao 
EID\&A - Revista Eletrônica de Estudos Integrados em Discurso e Argumentação, Ilhéus, n. 15, jan./jun.2018.

valor atribuído ao agente. A ocorrência dessa transferência e valores independe de o ato ser isolado ou repetido diversas vezes. Asseveram os autores que, para evitar que um ato isolado reaja sobre a pessoa, é necessário o emprego de técnicas argumentativas específicas.

Ora, se os atos praticados pelos réus são, a priori, altamente reprováveis, como justificar a decisão absolutória? O acórdão lança mão da interpretação pela intenção. Sobre essa técnica, Perelman e Olbrechts-Tyteca discorrem:

Toda argumentação moral baseada da intenção é uma moral do agente, devendo ser oposta a uma moral do ato, muito mais formalista. O exemplo acima, por fazer intervir agentes tão caracterizados como Deus e Satã, mostra muito bem o mecanismo desses argumentos, mas não há controvérsia moral em que não sejam empregados. As intenções do agente, os motivos que lhe determinaram a ação, serão amiúde considerados como a realidade que se esconde atrás das manifestações puramente exteriores e que é preciso procurar conhecer através das aparências, pois são eles, afinal de contas, os únicos que teriam importância (PERELMAN; OLBRECHTS-TYTECA, 2005, p. 343-344).

No acórdão, os réus são associados a condutas diversas das práticas criminosas pelas quais foram acusados, extraídas dos depoimentos dos mesmos, bem como da vítima e de testemunhas. Nominalmente, o fato de $\mathrm{H}$. J. A. estar construindo uma casa na qual viveria maritalmente com E. S. S., a suposta ofendida: "[...] o Réu estava construindo uma casa para viverem juntos e constituírem família, sendo este tipo de situação considerada costumeira no Povoado de Teles" (TJ-BA, 2015, p. 7).

Outro fato que é levantado no acórdão para dissociar os réus do estigma gerado pela acusação é o de que C. S. R. A. teria vivido situação semelhante à de E. S. S., tendo inclusive expressado seu desejo de vê-la casada com H. J. A. na igreja: "Além disso, a Apelante confirmou os relatos judiciais da vítima, e, malgrado figurar como Ré na respectiva Ação Penal, ainda assim disse querer 'que Hilton vá morar com Eduarda e se casem direitinho na igreja' (sic)" (TJBA, 2015, p. 6-7).

A discrepância entre esses fatos e a conduta supostamente criminosa praticada revela que sua verdadeira intenção era a de constituir uma família aos moldes tradicionais, ignorando o fato de que a menor idade de E. S. S. a colocava na condição de vulnerável sob a ótica da Lei Penal, caracterizando o relacionamento sexualmente ativo entre H. J. A e E. S. S. como crime.

Além da interpretação pela intenção, o acórdão lança mão do que Perelman e Olbrechts-Tyteca (2005) denominam técnicas de refreamento 
EID\&A - Revista Eletrônica de Estudos Integrados em Discurso e Argumentação, Ilhéus, n. 15, jan./jun.2018.

opostas à relação ato-pessoa, empregadas quando se deseja evitar que o julgamento de valor relativo a um ato indica no valor atribuído à pessoa, ou que o oposto aconteça. Ao recorrer ao contexto social e às circunstâncias envolvendo os agentes para afastar a reprovabilidade de suas condutas, o acórdão se utiliza de uma técnica denominada preconceito ou prevenção:

\begin{abstract}
Uma dessas técnicas é o preconceito, ou melhor talvez, a prevenção. Interpretase e julga-se $o$ ato em função do agente, fornecendo este o contexto que permite compreender melhor aquele. Graças a isso, mantém-se uma adequação entre o ato e a concepção que tínhamos da pessoa. [... ]

Como a prevenção, o preconceito, favorável ou desfavorável, tem, muito amiúde, o efeito de cegar-nos sobre o valor do ato, de transferir para este outros valores provenientes do agente, abster-se do preconceito será operar uma ruptura salutar entre o ato e a pessoa (PERELMAN; OLBRECHTS-TYTECA, 2005, p. 358).
\end{abstract}

O melhor exemplo de emprego dessa técnica específica está na constatação de que a ré C. S. R. A. teria ela própria iniciado sua vida sexual muito cedo, considerando, portanto, comum o relacionamento entre H. J. A. e sua filha:

Do interrogatório de CLEIDE DOS SANTOS RODRIGUES (fls. 148/149), constata-se que esta teve seu primeiro filho com 14 anos de idade, tanto é que 'a interrogada tinha 12 anos quando começou a namorar com Edvaldo, por isso achou normal quando Eduarda engravidou-se e foi morar com Hilton'(sic) (TJBA, 2015, p. 6).

Como última estratégia argumentativa fundamentadora do argumento da inevitabilidade do erro de proibição no caso analisado, o acórdão recorre a mais uma ligação de coexistência, aquela entre o grupo e seus membros. Segundo Perelman e Olbrechts-Tyteca (2005), o valor relativo ao ato pode ser interpretado de acordo com os valores do indivíduo, que, por sua vez, podem ser percebidos como dependentes dos valores do grupo ao qual ele pertença. O acórdão trabalha com essa relação complexa ao evidenciar que os réus são membros de uma comunidade - o povoado de Teles - desprovida de recursos básicos como infraestrutura e educação, sem conhecimento das regras jurídicas, tendo agido, portanto, de acordo com os costumes do povoado. Utiliza a técnica de aproximação do indivíduo a um grupo, devendo o ato ser julgado por meio desse parâmetro. Se o relacionamento entre H. J. A. e E. S. S. era conhecido pelos membros da comunidade e visto como algo comum, que ocorre costumeiramente no povoado, não seria razoável uma perspectiva de condenação: 
EID\&A - Revista Eletrônica de Estudos Integrados em Discurso e Argumentação, llhéus, n. 15, jan./jun.2018.

Das testemunhas ouvidas em juízo, todas moradores do povoado e que conheciam os envolvidos mostraram, dessume-se que eles não sabiam que tratava-se de crime um rapaz relacionar-se com uma pessoa menor, sendo tal situação comum naquela localidade - a qual, frise-se, não possui energia elétrica nem água encanada, consoante relatou a vítima - principalmente quando, no caso de gravidez, eles se casavam [...] (TJ-BA, 2015, p. 7).

O acórdão insere os réus num contexto social específico e declara que suas intenções não apresentavam potencial lesivo. Dissocia da pessoalidade dos réus a reprovabilidade do ato praticado e assim o acórdão exclui a culpabilidade de suas ações. Legalmente, os argumentos empregados fundamentam a existência do erro de proibição invencível, ou seja, o desconhecimento da conduta criminosa praticada, suficientemente justificado pelas circunstâncias. É pela interação de diversas técnicas argumentativas, convergindo para a validação dessa tese singular, que o acórdão alcançou a adesão de seu auditório, pois produziu seus efeitos sem ter sido alvo de outros recursos judiciais ou pedidos de revisão de sua decisão.

\section{Considerações finais}

A partir da presente análise do Acórdão $n^{\circ}$ 000049927.2011.8.05.0246, no qual a Turma Recursal argumentou pela relativização do critério rígido estabelecido no art. 217-A do CPB para absolver os réus, observou-se a relevância do estudo das técnicas argumentativas empregadas em decisões judiciais. Denota-se que o gênero acórdão judicial figura como rico campo de análise para a argumentação desde a sua concepção até a contemporaneidade.

Amparado nas considerações sobre ethos e pathos, propostos por Maingueneau e Santana Neto, respectivamente, foi possível identificar as marcas próprias do gênero acórdão judicial e o modo como convergem para a formação de um discurso impessoal que intenciona representar a própria Justiça. Percebe-se que os elementos da tríade retórica se articulam na construção e uma argumentação bem-sucedida.

Foi possível identificar, na materialidade linguística analisada, a tentativa de estruturação de um ethos estabelecido previamente por meio de estereótipos clássicos do mundo do Direito, fazendo remissão a noções de autoridade imparcial e impessoal, numa tentativa de atribuir aos magistrados da Turma Recursal o caráter de "homens e mulheres do Direito", ou seja, 
EID\&A - Revista Eletrônica de Estudos Integrados em Discurso e Argumentação, Ilhéus, n. 15, jan./jun.2018.

representantes da sabedoria e da técnica judicial, capazes de apreender e transmitir ao mundo a verdadeira noção de Justiça.

No que diz respeito ao pathos, esclareceu-se que, embora a decisão se dirija aparentemente a um auditório amplo e heterogêneo, busca-se mover mais precisamente as emoções da comunidade jurídica - magistratura, advocacia, Ministério Público - a partir do momento em que se recorre a elementos de legalidade e autoridade judicial e técnica, afeitos às preferências desse auditório específico, que se atém aos estereótipos de imparcialidade já mencionados. Foi possível observar também que a decisão encoraja uma percepção específica dos fatos obtidos pelos elementos de prova, utilizando as próprias partes do processo na composição de uma narrativa capaz de coadunar com a argumentação empregada.

A análise do logos mostrou-se também bastante proveitosa, apontando o entrelaçamento de diversos argumentos de ligação de coexistência com o objetivo de dissociar a figura dos réus da valoração negativa que o crime de estupro possui e ao mesmo tempo associá-los à situação de precariedade e carência - material e informacional - da comunidade a qual pertencem. Não obstante essa engenhosa combinação entre associação e refreamento, o argumento de autoridade mostrou-se sempre presente, como forma de consubstanciar as demais técnicas, já que, como se depreende das análises do pathos e do logos, o próprio gênero judiciário do discurso busca amparar-se a todo momento no estereótipo da autoridade conhecedora do Direito, capaz de interpretá-lo e administrá-lo corretamente a cada caso.

Embora o artigo tenha se valido das categorizações de técnicas argumentativas elaboradas apenas por Perelman e Olbrechts-Tyteca, sem dúvida seria possível extrair do corpus outros procedimentos e estratégias, visto que o estudo da argumentação não se encontra encerrado, de modo que outras vias de análise podem enriquecer e diversificar trabalhos futuros.

\section{Fontes}

BRASIL. Código Penal. Decreto-lei n².848, de 7 de dezembro de 1940.

TJ-BA - APL: 00004992720118050246, Relator: Ivone Ribeiro Gonçalves Bessa Ramos, Primeira Câmara Criminal - Primeira Turma, Data de Publicação: 11/03/2015. Disponível em: $\quad$ hhttp://tj-ba.jusbrasil.com.br/jurisprudencia/362590965/apelacao-apl4992720118050246>. Acesso em: 08 ago. 2017. 
EID\&A - Revista Eletrônica de Estudos Integrados em Discurso e Argumentação, llhéus, n. 15, jan./jun.2018.

\section{Referências}

FIORIN, José Luiz. Argumentação. 1.ed. São Paulo: Contexto. 2016.

MAINGUENEAU, Dominique. Cenas da Enunciação. Org. e trad. Sírio Possenti e Maria Cecília Pérez de Souza-e-Silva. São Paulo: Parábola Editorial, 2008.

GUILHERME Nucci. O crime de estupro sobre o prisma da Lei 12.015/19. 2014. Disponível em <http://www.guilhermenucci.com.br/artigo/o-crime-de-estupro-sob-oprisma-da-lei-12-01509>. Acesso em 12 ago. 2017.

PERELMAN, Chaïm; OLBRECHTS-TYTECA, Luci. Tratado da argumentação: a nova retórica. Trad. Maria Ermantina de Almeida Prado Galvão. 2.ed. São Paulo: Martins Fontes, 2005.

PERELMAN, Chaïm. Lógica jurídica. Trad. de Verginia K. Pupi. São Paulo: Martins Fontes. 1998.

REBOUL, Olivier. Introdução à retórica. Trad. de Ivone Castilho Benedetti. 2.ed. São Paulo: Martins Fontes, 2004.

SANTANA NETO, João Antônio de. O Páthos na Argumentação. In: 1a JIED - Jornada Internacional de Estudos do Discurso. 2008. Não paginado. Disponível em: http://www.dle.uem.br/jied/pdf/O\%20P\%C1THOS\%20NA\%20ARGUMENTA\%C7\%C3O\%20s antana\%2oneto.pdf. Acesso em: 11 ago. 2017.

Forma de citação sugerida:

NEVES, Marcelo Pereira; SOBRAL, Gilberto Nazareno Telles. Erro de proibição e estupro de vulnerável: análise argumentativa de acórdão judicial. EID\&A - Revista Eletrônica de Estudos Integrados em Discurso e Argumentação, Ilhéus, n. 15, p. 143161, jan./jun.2018.

Recebido em: 22/03/2018

Aprovado em: 15/06/2018 